\title{
ANURANS FROM BARRA DE LA LAGUNA DE ROCHA (ROCHA, URUGUAY) ANUROS DE BARRA DE LA LAGUNA DE ROCHA (ROCHA, URUGUAY)
}

\author{
Gisela Pereira ${ }^{1 *}$, Ernesto Elgue ${ }^{1}$ and Raúl Maneyro ${ }^{1}$ \\ ${ }^{1}$ Laboratorio de Sistemática e Historia Natural de Vertebrados, Facultad de Ciencias, Universidad de la República, Iguá 4225, C. P. 11400, Montevideo, \\ Uruguay. \\ "Correspondence: gisepe04@gmail.com
}

Resumen.- En este estudio presentamos una lista de especies de anfibios del Área Protegida Barra de la Laguna de Rocha (BLR), Uruguay. Se realizaron 15 salidas de campo de tres días de duración entre setiembre 2011 y marzo 2013. Durante cada salida de campo, se realizó búsqueda activa de individuos y muestreos auditivos en cada uno de los siete sitios seleccionados. Registramos 19 especies de anuros, distribuidas en seis familias: Bufonidae (4 especies), Hylidae (5), Leptodactylidae (7), Microhylidae (1) y Odontophrynidae (2). A partir de la comparación de estos datos con los registros históricos (obtenidos de colecciones científicas y literatura), identificamos ocho especies nuevas para el sitio de estudio. La riqueza de especies en el área representa un $39.6 \%$ de la riqueza total registrada para Uruguay y se destaca la presencia de Melanophryniscus montevidensis (Philippi, 1902), una especie en Peligro Crítico (CR) a nivel nacional, y globalmente Vulnerable (VU). La información de la composición de especies de anfibios en la BLR, pretende contribuir en la implementación del plan de manejo de esta unidad de conservación, así como estimular la realización de futuros estudios en el área.

Palabras clave.-Amphibia, conservación, lista de especies, área protegida.

Abstract.- We present a list of amphibian species from the protected area Barra de la Laguna de Rocha (BLR), Uruguay. Fifteen monthly three-day field trips were conducted between September 2011 and March 2013. During each field trip, active searches of individuals and auditive samplings were performed at seven selected sites. We recorded 19 species of amphibians belonging to five families: Bufonidae (4 especies), Hylidae (5), Leptodactylidae (7), Microhylidae (1) and Odontophrynidae (2). Comparing these data with historical records (obtained from cientific collections and literature), eight species represented new records for the study site. The species richness in the area represents $39.6 \%$ of the total richness recorded for Uruguay. We highlight the presence of Melanophryniscus montevidensis (Philippi, 1902), a Critically Endangered (CR) species at national level, and globally Vulnerable (V). Information on BLR's amphibian species composition could help in the implementation of the management plan for this conservation unit, as well as to stimulate future studies in the area.

Keywords.- Amphibia, conservation, lists of species, protected area.

\section{INTRODUCTION}

Inventory and wildlife monitoring studies are basic and essential for planning conservation strategies in natural areas (Heyer et al., 1994; Maneyro \& Carreira, 2006). Information on species richness is useful for directing conservation efforts, as it allows to define the current status of local populations through comparison with historical records (Bardier \& Maneyro, 2015). Additionally, an inventory of species can be employed to establish conservation priorities within a specific area (Heyer et al., 1994).
Amphibian populations have suffered widespread declines and extinctions in recent decades. Currently, amphibians are the most threatened vertebrate group worldwide (Stuart et al., 2004, 2008; Collins \& Crump, 2009; IUCN, 2018). Due to their biological and physiological characteristics (e.g., ectotherm condition, permeable skin, biphasic life cycles; Wells, 2007), these animals are particularly vulnerable to habitat loss, changes in water and soil quality, and to potential impacts of climate change (Stuart et al., 2004, 2008; Collins \& Crump, 2009). 
Paisaje Protegido Laguna de Rocha is a protected area located in Southern Uruguay, being Barra de la Laguna de Rocha one of its conservation focal objects. Currently, there is no official inventory of the amphibian species from this area based on systematic samples. Previous reports (e.g., Maneyro et al., 1995; Núñez et al., 2004), mention records of some species for this locality and nearby areas. However, these data are scarce and do not come from systematized studies. Long-term field samplings become essential, in order to provide a complete and updated characterization of the amphibian fauna composition.

The aims of this study were to obtain the inventory of amphibian species occurring in the southern sector of this conservation unit (Rocha, Uruguay); to compare this inventory with the historical records available in scientific collections and literature; and to suggest which species may be priorities for conservation in the area. This study aims to contribute to the implementation of the management plan for this protected area, as well as to stimulate further studies in the BLR.

\section{MATERIALS AND METHODS}

The study was carried out at sites surrounding the southern coast of Laguna de Rocha, locally known as Barra de la Laguna

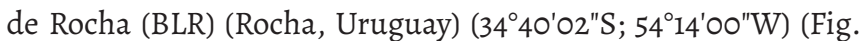
1). Since 1976, this area is part of the biosphere reserve Bañados del Este, included in the UNESCO Man and Biosphere Program (MAB), due to its great biodiversity (Pezzani, 2007). The lagoon has a great touristic activity and its sandy environments represent really important habitats for amphibians (Maneyro

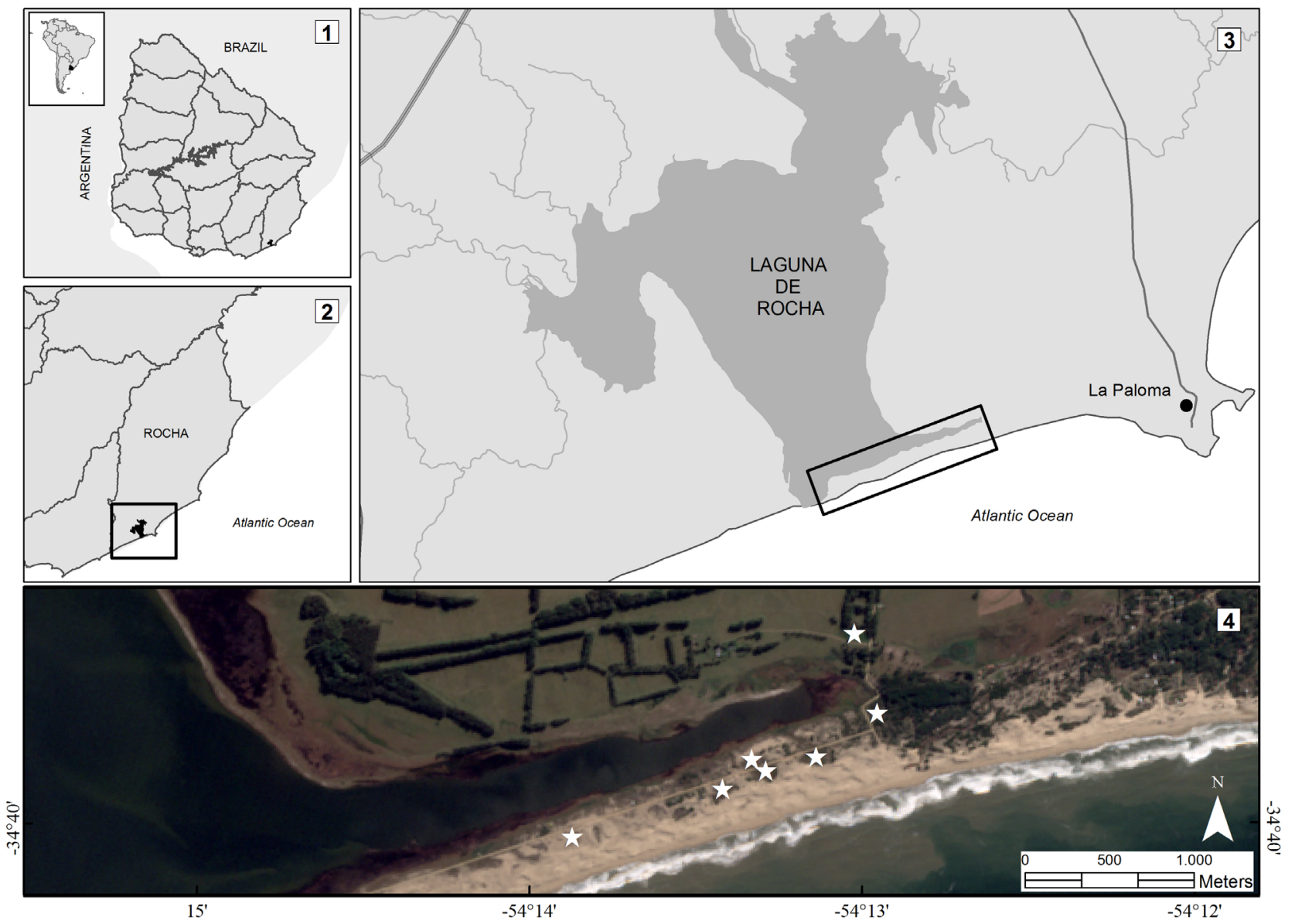

Figura 1. Área de estudio. 1) Mapa de Uruguay. 2) Departamento de Rocha. El recuadrado negro indica la Laguna de Rocha. 3) Laguna de Rocha. El rectángulo indica la zona Barra de la Laguna de Rocha (BLR). 4) Sitios de muestreo seleccionados en BLR (Imagen de satélite Sentinel II; fecha: 20 de julio de 2017).

Figure 1. Study area. 1) Map of Uruguay. 2) Rocha department. The black square indicates the Laguna de Rocha. 3) Laguna de Rocha. The rectangle indicates the Barra de la Laguna de Rocha (BLR) zone. 4) Selected sampling sites in BLR (Sentinel II satellite image; date: July 20, 2017). 
et al., 1995). At moment, this area is part of Paisaje Protegido Laguna de Rocha ( $34^{\circ} 37^{\prime} 59^{\prime \prime} \mathrm{S}, 54^{\circ} 17^{\prime} 40^{\prime \prime} \mathrm{W}$ ), an area that belongs to the National System of Protected Areas (SNAP) (DINAMA, 2010). It exhibits a coastal sand dune system, located at the southern portion of the lagoon, these areas are the most critically endangered within the protected area, and require strict conservation measures. The dunes have associated flood prone meadows, with shallow temporary ponds ( $<30 \mathrm{~cm}$ deep) of variable sizes and sandy substrata. Amphibians use these ponds during the breeding activity. The high concentration of salt in the environment determines a halophyte vegetation cover (Trimble et al., 2003). The climate is subtropical, with an average annual temperature of $16.4{ }^{\circ} \mathrm{C}$ and an average annual accumulated rainfall of $1058.7 \mathrm{~mm}$ (Tutiempo Network, 2019).

In order to obtain the list of species in BLR, fifteen monthly three-day field trips were performed in September 2011, November 2011 and between March 2012 and February 2013. Seven sampling sites were selected (Fig. 1). These sites comprise the breeding water bodies and their surroundings. Individuals were sought at the selected sites through active visual search (Heyer et al., 1994), with a sampling effort of at least 3 hours per day. In addition, fifteen-minute acoustic samplings (Heyer et al., 1994) were performed at all sites throughout three monitoring shifts (morning: 08:00-13:00 h, afternoon:14:00-19:00 h, evening: 20:00-24:00 h). Additionally, historical records of species for the study site were obtained from the literature (Maneyro et al., 1995; Núñez et al., 2004), and were complemented with those obtained from the review of the Colección Científica de la Facultad de Ciencias of the Universidad de la República (ZVCB). For taxonomical determination of observed specimens were used local field guides (Maneyro \& Carreira, 2012), and acoustic records of known species were employed for comparisons.

Finally, the list of species obtained was compared with the historical records. The conservation status of the species was determined using as a main reference the national Red List (Carreira \& Maneyro, 2015). Some specimens were photographed, and the photo vouchers were deposited at the Colección Fotográfica de la Facultad de Ciencias - Anfibios (CFB). Also, some voucher specimens were collected and stored at Colección Científica de la Facultad de Ciencias of the Universidad de la República, for which, a collection license was issued by the national authority (División Fauna de la Dirección de Recursos Naturales Renovables of the Ministerio de Ganadería, Agricultura y Pesca). The specimens were euthanized in the field following the protocols approved by the Comision Honoraria de Experimentación Animal associated with the project ANII FCE 2514.

\section{RESULTS}

Nineteen anuran species were identified from BLR. These species are distributed in 11 genera belonging to five families: Bufonidae (4 species), Hylidae (5), Leptodactylidae (7), Microhylidae (1) and Odontophrynidae (2) (Table 1, Figs. 2 and 3). Considering the historical records of species for the study area, the presence of 11 species in the BLR was confirmed, and 8 new species were recorded: Dendropsophus sanborni (Schmidt, 1944); Scinax granulatus (Peters, 1871); Leptodactylus latinasus (Jiménez de la Espada, 1875); Leptodactylus mystacinus (Burmeister, 1861); Physalaemus gracilis (Boulenger, 1883); Pseudopaludicola falcipes (Hensel, 1867); Elachistocleis bicolor (Guérin-Méneville, 1838) and Odontophrynus maisuma (Rosset, 2008).

Within the total recorded species, only Melanophryniscus montevidensis (Philippi, 1902) is threatened in Uruguay (Carreira and Maneyro, 2015). This species is cataloged as Vulnerable (VU) at global scale (Langone, 2004), whereas at the national level it is considered Critically Endangered (CR) (Carreira \& Maneyro, 2015). It was observed in the study area during the diurnal and nocturnal samplings, associated with temporary ponds during different breeding events. Another species, Odontophrynus maisuma, is locally Near Threatened (NT) (Carreira \& Maneyro, 2015), but due to its recent description, its conservation status has not been globally evaluated (IUCN, 2018). The remaining 17 species are considered as Least Concern (LC) for their conservation status, both locally and globally (IUCN, 2018, Carreira and Maneyro, 2015) (Table 1).

\section{DISCUSSION}

Currently there are 49 amphibian species inhabiting Uruguay (Maneyro \& Carreira, 2012); and a large number are distributed throughout the coastal areas of the country (Maneyro and Carreira, 2006). The Rocha Department is known for its high diversity of amphibians (Maneyro et al., 1995), and it has the highest species richness in Uruguay (26 species) (Núñez et al., 2004). The amphibian richness found during this study (19 species) was similar in comparison to some localities within the Rocha Department. In the coastal locality of Aguas Dulces 20 species were recorded (González \& Gambarotta, 2001), while from La Coronilla, Nuñez et al. (2004) reported 16 species, and more recently, Bardier and Maneyro (2015) enlisted 23 species in Cerro Verde (historical records of the area were included). Moreover, the number of species in the BLR exceeded the species richness found in Cabo Polonio (11 species) (López, 2006), and Laguna de Castillos (13 species) (Gambarotta et al., 1999). The amphibian species richness in BLR represents $39.6 \%$ of the total 
Tabla 1. Lista de especies de anuros de Barra de la Laguna de Rocha, Uruguay. A: registro auditivo; V: registro visual; Estatus en la UICN: estado de conservación de la UICN (UICN, 2018); Estado de NC: estado de conservación nacional (Carreira \& Maneyro, 2015): CR: en peligro crítico; LC: Menor preocupación; NE: no evaluado; NT: Casi amenazado; VU: Vulnerable. * La especie no se puede distinguir de otros taxones simpátricos a través del registro auditivo. ${ }^{* *}$ Los asteriscos indican posibles especies prioritarias para la conservación en Barra de la Laguna de Rocha.

Table 1. Species list of anurans from Barra de la Laguna de Rocha, Uruguay. A: auditive record; V: visual record; IUCN status: IUCN conservation status (IUCN, 2018); NC status: National conservation status (Carreira \& Maneyro, 2015): CR: Critically endangered; LC: Least concern; NE: Not evaluated; NT: Near threatened; VU: Vulnerable. * The species cannot be distinguished from other sympatric taxa through the auditive record. ${ }^{* *}$ Asterisks indicate potential prioritary species for conservation in Barra de la Laguna de Rocha.

\begin{tabular}{|c|c|c|c|c|}
\hline Family/Species & Voucher number & Recording method & IUCN status & NC status \\
\hline \multicolumn{5}{|l|}{ Family Bufonidae } \\
\hline Melanophryniscus montevidensis (Philippi, 1902) & ZVCB 23422; 23423 and 23424 & $A / V$ & VU & $C R^{* *}$ \\
\hline Rhinella arenarum (Hensel, 1867) & ZVCB 4900 and 22670. & $\mathrm{~A} / \mathrm{V}$ & LC & LC \\
\hline Rhinella dorbignyi (Duméril \& Bibron, 1841) & CF-B 039 & $* / V$ & LC & $\mathrm{LC}$ \\
\hline Rhinella fernandezae (Gallardo, 1957) & ZVCB 22592. & $* / \mathrm{V}$ & LC & LC \\
\hline \multicolumn{5}{|l|}{ Family Hylidae } \\
\hline Dendropsophus sanborni (Schmidt, 1944) & CF-B 040, 041 and 046. & $\mathrm{~A} / \mathrm{V}$ & LC & LC \\
\hline Boana pulchella (Duméril \& Bibron, 1841) & ZVCB 22769; 22920 and 22921. & $A / V$ & LC & LC \\
\hline Pseudis minuta Günther, 1858 & ZVCB 22547; 22548 and 22607; CF-B 049. & $A / V$ & LC & LC \\
\hline Scinax granulatus (Peters, 1871) & ZVCB 22850. & $A / V$ & LC & LC \\
\hline Scinax squalirostris (Lutz, 1925) & ZVCB 16145 and 22609; CF-B 050. & $A / V$ & LC & LC \\
\hline \multicolumn{5}{|l|}{ Family Leptodactylidae } \\
\hline Leptodactylus gracilis (Duméril \& Bibron, 1841) & ZVCB 22604; 22605 and 22737. & $A / V$ & LC & LC \\
\hline Leptodactylus latinasus (Jiménez de la Espada, 1875) & ZVCB 23403 & $A / V$ & LC & $L C$ \\
\hline Leptodactylus latrans (Steffen, 1815) & $\begin{array}{c}\text { ZVCB } 22622 \text { and 22625; CF-B } 045 \text { and } \\
047 .\end{array}$ & $A / V$ & LC & LC \\
\hline Leptodactylus mystacinus (Burmeister, 1861) & ZVCB 23398. & $A / V$ & LC & LC \\
\hline Physalaemus biligonigerus (Cope, 1861) & CF-B 048. & $* / \mathrm{V}$ & LC & LC \\
\hline Physalaemus gracilis (Boulenger, 1883) & CF-B 042 & $* / \mathrm{V}$ & LC & LC \\
\hline Pseudopaludicola falcipes (Hensel, 1867) & CF-B 043 and 044. & $A / V$ & LC & LC \\
\hline \multicolumn{5}{|l|}{ Family Microhylidae } \\
\hline Elachistocleis bicolor (Guérin-Méneville, 1838) & ZVCB 23399; 23400 and 23401. & $A / V$ & LC & LC \\
\hline \multicolumn{5}{|l|}{ Family Odontophrynidae } \\
\hline Odontophrynus americanus (Duméril \& Bibron, 1841) & ZVCB 16142 & $* / V$ & LC & LC \\
\hline Odontophrynus maisuma (Rosset, 2008) & ZVCB 22736; 22743 and 22841. & $* / \mathrm{V}$ & $\mathrm{NE}$ & $N T^{* *}$ \\
\hline
\end{tabular}

richness recorded for Uruguay, and $73.1 \%$ of the total species richness recorded for Rocha. Consequently, the study site could be considered as an area with a high diversity of amphibian species.
This study allows to expand the historical record of species for the area, since eight new species were found during the sampling period. These new records reflect an optimal sampling effort, since in this study the monitoring was carried out in the 


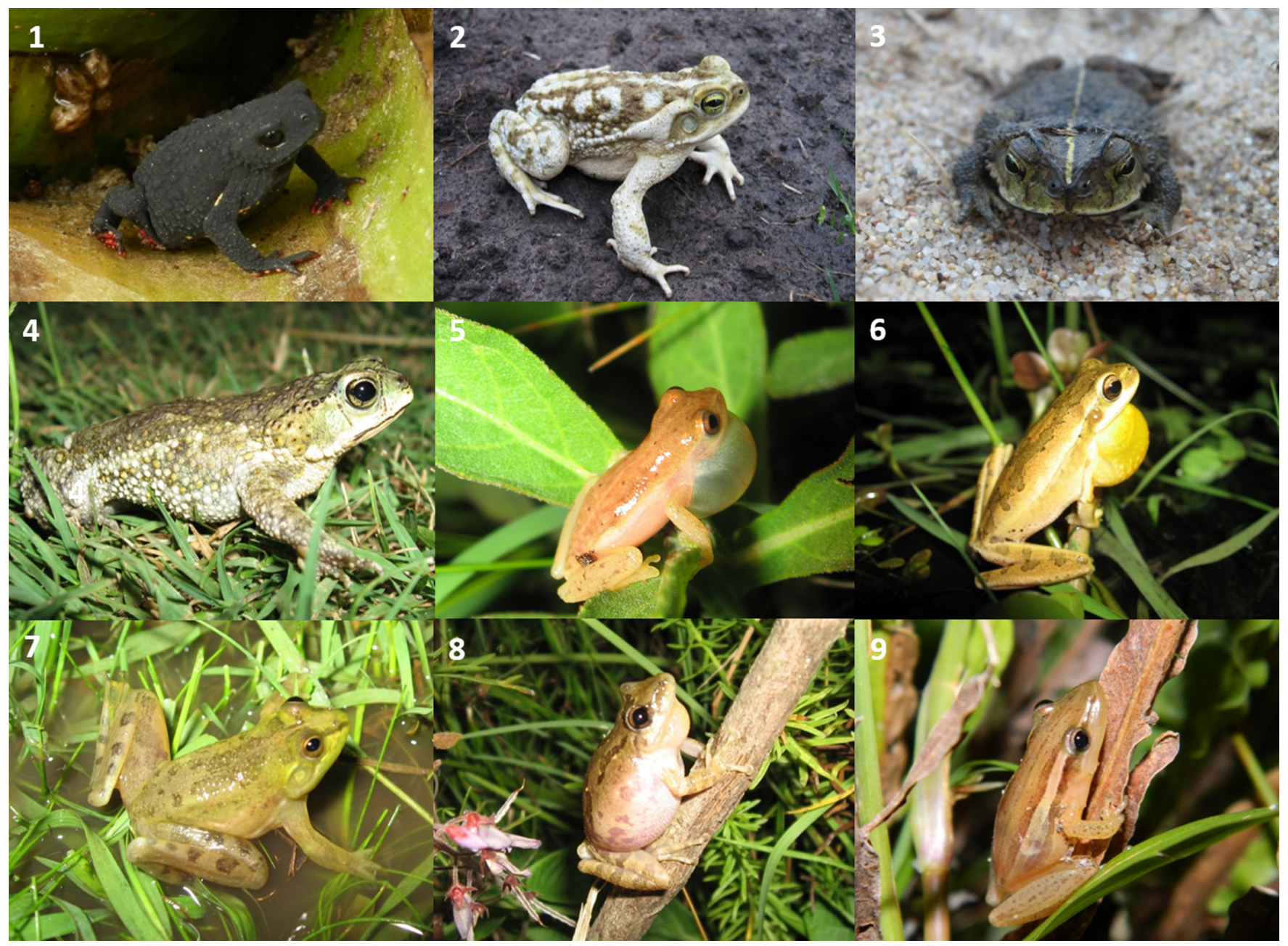

Figura 2. Especies encontradas durante el periodo de muestreo en Barra de la Laguna de Rocha: 1) Melanophryniscus montevidensis, 2) Rhinella arenarum, 3) Rhinella dorbignyi, 4) Rhinella fernandezae, 5) Dendropsophus sanborni, 6) Boana pulchella, 7) Pseudis minuta, 8) Scinax granulatus, 9) Scinax squalirostris. Todas las fotos de Raúl Maneyro excepto por la 1 tomada por Ernesto Elgue.

Figure 2. Species found during the sampling period in Barra de la Laguna de Rocha: 1) Melanophryniscus montevidensis, 2) Rhinella arenarum, 3) Rhinella dorbignyi, 4) Rhinella fernandezae, 5) Dendropsophus sanborni, 6) Boana pulchella, 7) Pseudis minuta, 8) Scinax granulatus, 9) Scinax squalirostris.All photos by Raúl Maneyro except for 1, by Ernesto Elgue.

long-term, covering all the seasons of the year, as well as the different times of the day, and combining acoustic and visual sampling. These two sampling methods were complementary and contributed to make the data collection more precise. This permitted us to differentiate between species that are often confused using only the auditive record, as is the case of Rhinella dorbignyi (Duméril \& Bibron, 1841) and R. fernandezae (Gallardo, 1957); Physalaemus biligonigerus (Cope, 1861) and P. gracilis; Odontophrynus americanus (Duméril \& Bibron, 1841) and O. maisuma.
Another aspect to be highlighted is that some samplings included periods with high levels of rainfall, which allowed us to register the presence of explosive-breeder species, whose reproductive activity is brief and occurs after heavy rainfalls (Wells, 2007). Some species with these characteristics in the study area are: Melanophryniscus montevidensis, Elachistocleis bicolor and Odontophrynus americanus. During the sampling period Pleurodema bibroni (Tschudi, 1838) was not recorded in BLR. This draws our attention as within the study area there are well preserved sites and geographically close records for this species (Kolenc et al., 2009, 2012). Pleurodema bibroni is nationally 

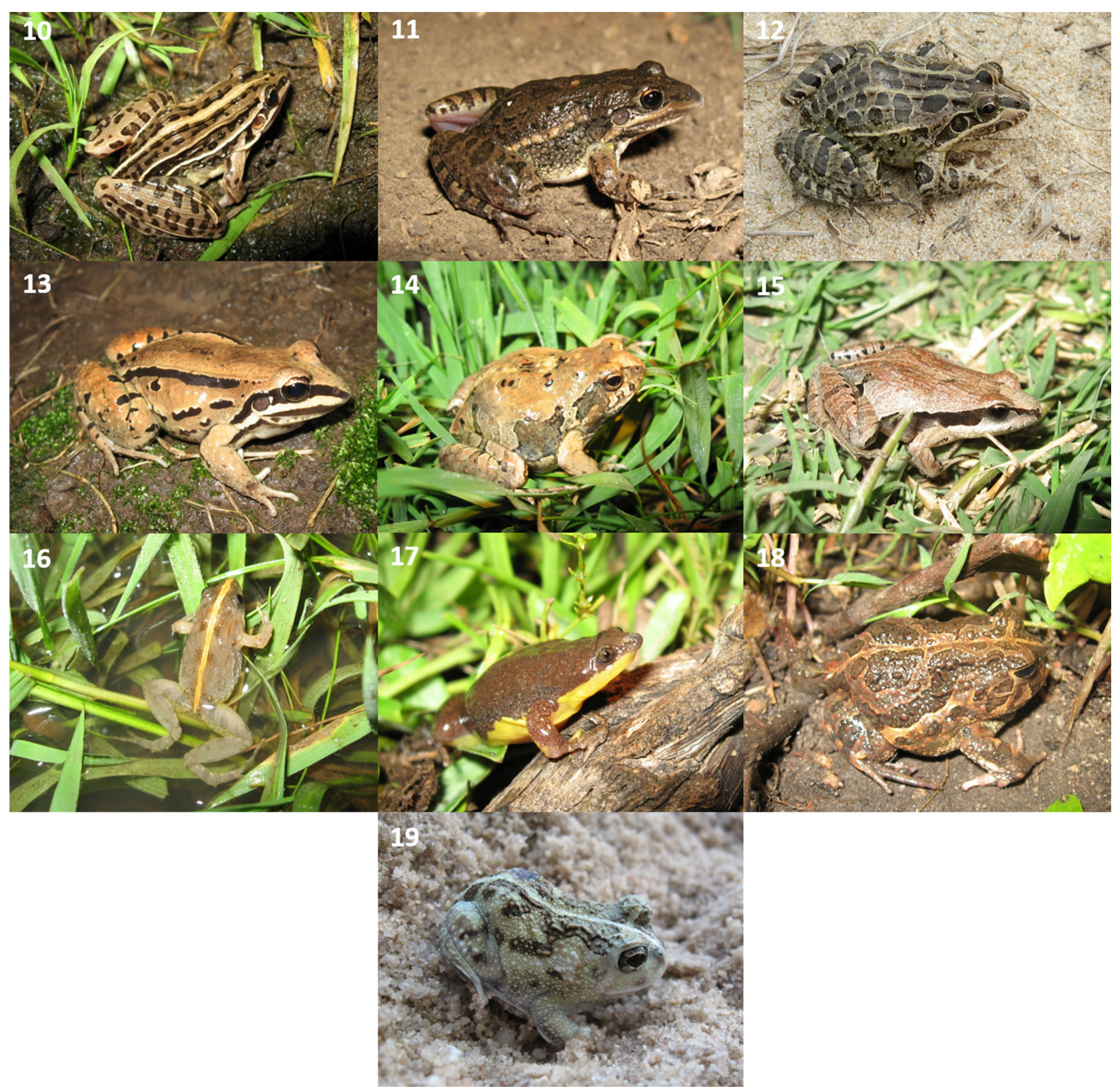

Figura 3. Especies encontradas durante el periodo de muestreo en Barra de la Laguna de Rocha: 10) Leptodactylus gracilis, 11) Leptodactylus latinasus, 12) Leptodactylus latrans, 13) Leptodactylus mystacinus, 14) Physalaemus biligonigerus, 15) Physalaemus gracilis, 16) Pseudopaludicola falcipes, 17) Elachistocleis bicolor, 18) Odontophrynus americanus, 19) Odontophrynus maisuma. Todas las fotos de Raúl Maneyro excepto por la 12), tomada por Ernesto Elgue.

Figure 3. Species found during the sampling period in Barra de la Laguna de Rocha: 10) Leptodactylus gracilis, 11) Leptodactylus latinasus, 12) Leptodactylus (atrans, 13) Leptodactylus mystacinus, 14) Physalaemus biligonigerus, 15) Physalaemus gracilis, 16) Pseudopaludicola falcipes, 17) Elachistocleis bicolor, 18) Odontophrynus americanus, 19) Odontophrynus maisuma. All photos by Raúl Maneyro except for 12), by Ernesto Elgue.

listed as near threatened (NT) (Carreira \& Maneyro, 2015), and its populations have declined in recent years (Kolenc et al., 2009,
2012), which leads us to think they may have disappeared from the study site. Melanophryniscus montevidensis should be considered 
as a priority species for conservation in BLR. This species is restricted to the Uruguayan coasts and Brazil (Bernardo-Silva et al., 2012). It is critically endangered in Uruguay (Carreira \& Maneyro, 2015), due to its drastic population decline, small extension of occurrence (less than $10 \mathrm{~km} 2$ ), habitat deterioration and the growing urbanization of the coastal areas, among others (Langone, 2004; Arrieta et al., 2013).

Additionally, the species is threatened by the consequences of climate change (Toranza \& Maneyro, 2013; Zank et al., 2014). In the BLR the breeding activity of $M$. montevidensis occurs in shallow temporary water bodies with abundant emergent hydrophilic vegetation (Pereira \& Maneyro, 2016a). This species also presents high fidelity to both breeding and shelter sites (mainly rushes and caraguatales near the breeding ponds) (Pereira \& Maneyro, 2016b). This information is essential and should be considered in the implementation of the management plan for the area, given that the increasing urbanization of the coastal area and the habitat fragmentation are two of the main causes considered for the decrease in their populations (Carreira \& Maneyro, 2015).

This is the first inventory of amphibians from BLR and represents a new contribution for a better knowledge of the local herpetofauna. The study area proved to be of great potential importance for the preservation of amphibian populations because it has a great diversity, comparable with other localities of greater area within the Rocha department. It also highlights the presence of a threatened species at local and global scale. Paisaje Protegido Laguna de Rocha belongs to SNAP since 2010, and the management plan is being recently implemented. Considering this aspect, the information about the richness and species distribution is fundamental to propose long-term conservation measures with the aim of protecting the amphibian biodiversity in BLR.

Acknowledgements.- We are very grateful to the colleagues of Laboratorio de Sistemática e Historia Natural de Vertebrados and the park rangers of Laguna de Rocha for supporting our field work. The authors acknowledge the financial support of Agencia Nacional de Investigación e Innovación (ANII) (Project FCE 2009-2514 given to RM).

\section{CITED LITERATURE}

Arrieta, A., C. Borteiro, F. Kolenc \& J.A. Langone. 2013. Anfibios. In: Soutullo A, Clavijo C, Martínez-Lanfranco JA (Eds) Especies prioritarias para la conservación en Uruguay. Vertebrados, moluscos continentales y plantas vasculares. SNAP/DINAMA/ MVOTMA y DICYT/MEC, Montevideo, 113-127.

Bardier, C. \& R. Maneyro. 2015. Inventory and conservation priorities for amphibian species from Cerro Verde (Rocha, Uruguay) and surroundings. Check List 11:1-8.

Bernardo-Silva, J., C. Martins-Ferreira, R. Maneyro \& T.R. Ochotorena de Freitas. 2012. Identification of Priority Areas for Conservation of Two Endangered Parapatric Species of Red-bellied Toads Using Ecological Niche Models and Hotspot Analysis. Natureza \& Conservação 10:207-213.

Boulenger, G.A. 1883. Notes on little-known species of frogs. Annals and Magazine of Natural History 11:16-19.

Burmeister, H. 1861. Reise durch die La Plata-Staaten mit besonderer Rücksicht auf die Physische Beschaffenheit und den Culturzustand. Ausgeführt in den Jahren 1857, 1858, 1859 und 1860. Volume 2. Halle: H. W. Schmidt.

Carreira, S. \& R. Maneyro. 2015. Lista Roja de los Anfibios y Reptiles del Uruguay. Una evaluación del estado de conservación de la herpetofauna de Uruguay sobre la base de los criterios de la Unión Internacional para la Conservación de la Naturaleza. Dirección Nacional de Medio Ambiente, Montevideo.

Collins, J.P. \& M.L. Crump. 2009. Extinction in our times. Global amphibian decline. Oxford University Press, New York.

Cope, E.D. 1861-"1860". Descriptions of new species of the reptilian genera Hyperolius, Liuperus and Tropidodipsas. Proceedings of the Academy of Natural Sciences of Philadelphia 12: 517-518.

DINAMA. 2010. Plan de mediano plazo 2010/2014. Sistema Nacional de Áreas Protegidas de Uruguay. Hemisferio Sur, Montevideo.

Duméril, A.M.C. \& G. Bibron. 1841. Erpétologie Générale ou Histoire Naturelle Complète des Reptiles. Volume 8. Paris: Libraire Encyclopédique de Roret.

Gallardo, J.M. 1957. Las subespecies argentinas de Bufo granulosus Spix. Revista del Museo Argentino de Ciencias Naturales Bernardino Rivadavia (Serie Zoológica) 3:337-374.

Gambarotta, J.C., A. Saralegui \& E.M. González. 1999. Vertebrados tetrápodos del Refugio de Fauna Laguna de Castillos, Departamento de Rocha. Relevamientos de Biodiversidad, 3:1-31. 
González, E.M. \& J.C. Gambarotta. 2001. Anfibios de Aguas Dulces, Departamento de Rocha, Uruguay (Amphibia: Anura). Relevamientos de Biodiversidad 5:1-7.

Guérin-Méneville, F.É. 1838. Iconographie du Règne Animal de G. Cuvier ou Représentation d'Après Nature de lune des espèces les plus Remarquables et Souvent non Envole Figurées, de Chaque Genre d'Animaux, avec un Texte Descriptif mis au Courant de La Science. Volume 3 (PartReptiles). Paris: J. B. Bélière.

Günther, A.C.L.G. 1858. Neue Batrachier in der Sammlung des britischen Museums. Archiv für Naturgeschichte. Berlin 24:319328.

Hensel, R. 1867. Beiträge zur Kenntnis der Wirbelthiere Südbrasilens. Archiv für Naturgeschichte. Berlin 33:120-162.

Heyer, W.R., M.A. Donnelly, R.W. McDiarmid, L.A.C. Hayek \& M.S. Foster. 1994. Medición y Monitoreo de la Diversidad Biológica. Métodos Estandarizados para Anfibios. Editorial Universitaria de la Patagonia, Chubut.

IUCN. 2018. IUCN Red List of Threatened Species. Version 2018-2. http://www.iucnredlist.org. [Accessed on November 2018].

Jiménez de la Espada, M. 1875. Iconographie du Règne Animal de G. Cuvier ou Représentation d'Après Nature de lune des espèces les plus Remarquables et Souvent non Envole Figurées, de Chaque Genre d'Animaux, avec un Texte Descriptif mis au Courant de La Science. Volume 3 (Part Reptiles). Paris: J. B. BalliËre.

Kolenc, F., C. Borteiro, D. Baldo, D.P. Ferraro \& C. Prigioni. 2009. The tadpoles and advertisement calls of Pleurodema bibroni Tschudi and Pleurodema kriegi (Müller), with notes on their geographic distribution and conservation status (Amphibia, Anura, Leiuperidae). Zootaxa 1969:1-35.

Kolenc, F., C. Borteiro, E.M. Gonzalez, D.A. Barrasso \& C. Prigioni. 2012. Recent findings of the declining frog Pleurodema bibroni Tschudi, 1838 (Anura: Leiuperidae) in Uruguay. Herpetology Notes 5:181-183.

Langone, J. 2004. Melanophryniscus montevidensis. IUCN Red List of Threatened Species 2004: http://dx.doi.org/10.2305/IUCN. UK.2004.RLTS.T54824A11210277. [Accessed on August 2018].

López, C.A. 2006. Relevamiento in situ de la herpetofauna de Cabo Polonio, Uruguay. Boletín de la Sociedad Zoológica de Uruguay 2a época 15:19-22.
Lutz, A. 1925. Batraciens du Brésil. Comptes Rendus et Mémoires Hebdomadaires des Séances de la Société de Biologie et des ses Filiales. Paris 93:211-214.

Maneyro, R., F. Forni \& M. Santos. 1995. Anfibios del departamento de Rocha. PROBIDES, Serie Divulgación Técnica I, Rocha.

Maneyro, R. \& S. Carreira. 2006. Herpetofauna de la costa uruguaya. In: Menafra R, Rodríguez-Gallego L, Scarabino F, Conde D (Eds) Bases para la conservación y el manejo de la costa uruguaya. Vida Silvestre, Montevideo, 233-246.

Maneyro, R. \& S. Carreira. 2012. Guía de anfibios de Uruguay. Ediciones de la Fuga, Montevideo.

Núñez, D., R. Maneyro, J.A. Langone \& R. de Sá. 2004. Distribución geográfica de la fauna de anfibios del uruguay. Smithsonian Herpetological Information Service 134:1-34.

Pereira, G. and R. Maneyro. 2016a. Use of Reproductive Microhabitat by Melanophryniscus montevidensis (Anura: Bufonidae) from Uruguay. Zoological Science 33:337-344.

Pereira, G. \& R. Maneyro. 2016b. Movement Patterns in a Uruguayan Population of Melanophryniscus montevidensis (Philippi, 1902) (Anura: Bufonidae) Using Photo-Identification for Individual Recognition. South American Journal of Herpetology 11:119-126.

Philippi, R.A. 1902. Suplemento a los Batraquios Chilenos Descritos en la Historia Física i Política de Chile de don Claudio Gay. Imp. E. Blanchard-Chessi, Santiago.

Peters, W.C.H.1871. Über einige Arten der herpetologischen Sammlung des Berliner zoologischen Museums. Monatsberichte der Königlichen Preussische Akademie des Wissenschaften zu Berlin 1871:644-652.

Pezzani, F. 2007. Reserva de Biosfera Bañados del Este, Uruguay. Documentos de Trabajo $\mathrm{N}^{\circ}$ 37. UNESCO (Programa de Cooperación Sur-Sur), París.

Rosset, S.D. 2008. New species of Odontophrynus Reinhardt and Lütken 1862 (Anura: Neobatrachia) from Brazil and Uruguay. Journal of Herpetology 42:134-144.

Schmidt, K.P. 1944. New frogs from Misiones and Uruguay. Field Museum of Natural History Publication. Zoological Series 29:153-160. 
Steffen, G.A. 1815. De Ranis nonnullis Observationes Anatomicae quas Consensu Gratiosae Facultatis Medicae. Berlin: Joannis Friderici Starckii.

Stuart, S.N., J.S. Chanson, N.A. Cox, B.E. Young, A.S.L. Rodrigues, D.L. Fischman \& R.W. Waller. 2004. Status and trends of Amphibian declines and extinctions worldwide. Science 306:1783-1786.

Stuart, S.N., M. Hoffmann, J.S. Chanson, N.A. Cox, R.J. Berridge, P. Ramani \& B.E. Young. 2008. Threatened Amphibians of the World. Lynx Edicions, Barcelona, Spain; IUCN, Gland, Switzerland; and Conservation International, Arlington, Virginia.

Toranza, C. and R. Maneyro. 2013. Potential effects of climate change on the distribution of an endangered species: Melanophryniscus montevidensis (Anura: Bufonidae). Phyllomedusa 12:97-106.

Trimble, M., M. Ríos, C. Passadore, M. Szephegyi, M. Nin, F. Garcia Olaso, C. Fagúndez \& P. Laporta. 2010. Ecosistemas costeros uruguayos: una guía para su conocimiento. Averaves, Cetáceos Uruguay, Karumbé. Editorial Imprenta Monteverde, Montevideo.

Tschudi, J.J.1838. Classification der Batrachier mit Berücksichtigung der fossilen Thiere dieser Abtheilung der Reptilien. Petitpierre, Neuchâtel.

Tutiempo Network, S.L. 2019. Clima Rocha. http://www.tutiempo. net/clima/ROCHA/865650.htm. Madrid, España. [Accessed on agosto 2019].

Wells, K.D. 2007. The Ecology and Behavior of Amphibians. The University of Chicago Press, Chicago.

Zank, C., F.G. Becker, M. Abadie, D. Baldo, R. Maneyro \& M. Borges Martins. 2014. Climate change and the distribution of neotropical Red-Bellied toads (Melanophryniscus, Anura, Amphibia): how to prioritize species and populations? PLoS One 9:e94625.

\section{APPENDIX I}

\section{Boana pulchella:}

ZVCB 22769 - January 23, 2013, Barra de la Laguna de Rocha, Rocha, Uruguay. Collectors: F. Achaval-Coppes, G. Pereira y E. Elgue.

ZVCB 22920 - February 23, 2013, Barra de la Laguna de Rocha, Rocha, Uruguay. Collectors: E. Elgue, F. Achaval-Coppes \& G. Pereira.

ZVCB 22921 - February 24, 2013, Barra de la Laguna de Rocha, Rocha, Uruguay. Collectors: E. Elgue, F. Achaval-Coppes \& G. Pereira.

\section{Dendropsophus sanborni:}

CF-B 040 - April 23, 2012, Barra de la Laguna de Rocha, Rocha, Uruguay. Photo by Ernesto Elgue.

CF-B 041 - March 26, 2012, Barra de la Laguna de Rocha, Rocha, Uruguay. Photo by Ernesto Elgue.

CF-B 046 - November 20, 2011, Barra de la Laguna de Rocha, Rocha, Uruguay. Photo by Gisela Pereira.

\section{Elachistocleis bicolor:}

ZVCB 23399 - October 31, 2012, Barra de la Laguna de Rocha, Rocha, Uruguay. Collectors: E. Elgue; F. Achaval-Coppes; C. Bardier; G. Pereira.

ZVCB 23400 - October 31, 2012, Barra de la Laguna de Rocha, Rocha, Uruguay. Collectors: E. Elgue; F. Achaval-Coppes; C Bardier; G. Pereira.

ZVCB 23401 - October 31, 2012, Barra de la Laguna de Rocha, Rocha, Uruguay. Collectors: E. Elgue; F. Achaval-Coppes; C. Bardier; G. Pereira.

\section{Leptodactylus gracilis:}

ZVCB 22604 - January 12, 1995, Laguna de Rocha, Rocha, Uruguay. Collectors: M. Santos \& R. Maneyro.

ZVCB 22605 - January 12, 1995, Laguna de Rocha, Rocha, Uruguay. Collectors: M. Santos \& R. Maneyro. 
ZVCB 22737 - April 24, 2012, Barra de la Laguna de Rocha, Rocha, Uruguay. Collectors: G. Pereira; E. Elgue; F. AchavalCoppes \& S. Cruces.

\section{Leptodactylus latinasus:}

ZVCB 23403 - October 31, 2012, Barra de la Laguna de Rocha, Rocha, Uruguay. Collectors: E. Elgue; F. Achaval-Coppes; C. Bardier; G. Pereira.

\section{Leptodactylus latrans:}

ZVCB 22622 - April 16, 1994, Laguna de Rocha, Rocha, Uruguay. Collectors: R. Maneyro, D. Queirolo, S. Umpierrez \& R. Rodriguez.

ZVCB 22625 - April 16, 1994, Laguna de Rocha, Rocha, Uruguay. Collectors: R. Maneyro, D. Queirolo, S. Umpierrez \& R. Rodriguez.

CF-B 045 - February 23, 2012, Barra de la Laguna de Rocha, Rocha, Uruguay. Photo by Gisela Pereira.

CF-B 047 - April 25, 2012, Barra de la Laguna de Rocha, Rocha, Uruguay. Photo by Ernesto Elgue.

\section{Leptodactylus mystacinus:}

ZVCB 23398 - October 30, 2012, Barra de la Laguna de Rocha, Rocha, Uruguay. Collectors: E. Elgue; F. Achaval-Coppes; C. Bardier; G. Pereira.

\section{Melanophryniscus montevidensis:}

ZVCB 23422 - October 30, 2012, Barra de la Laguna de Rocha, Rocha, Uruguay. Collectors: F. Achaval-Coppes, G. Pereira, C. Bardier \& E. Elgue.

ZVCB 23423 - October 30, 2012, Barra de la Laguna de Rocha, Rocha, Uruguay. Collectors: F. Achaval-Coppes, G. Pereira, C. Bardier \& E. Elgue.

ZVCB 23424 - October 30, 2012, Barra de la Laguna de Rocha, Rocha, Uruguay. Collectors: F. Achaval-Coppes, G. Pereira, C. Bardier \& E. Elgue.

Odontophrynus americanus:

ZVCB 16142 - August 7, 2006, Laguna de Rocha, Rocha,
Uruguay. Collectors: C. Borteiro, F. Kolenc.

\section{Odontophrynus maisuma:}

ZVCB 22736 - May 23, 2012, Barra de la Laguna de Rocha, Rocha, Uruguay. Collectors: G. Pereira; E. Elgue; V. Valdez; F. Achaval-Coppes \& S. Cruces.

ZVCB 22743 - August 22, 2012, Barra de la Laguna de Rocha, Rocha, Uruguay. Collectors: G. Pereira; E. Elgue; F. AchavalCoppes \& S. Cruces.

ZVCB 22841 - August 22, 2012, Barra de la Laguna de Rocha, Rocha, Uruguay. Collectors: S. Cruces, F. Achaval-Coppes, E. Elgue \& G. Pereira.

\section{Physalaemus biligonigerus:}

CF-B 048 - November 27, 2012, Barra de la Laguna de Rocha, Rocha, Uruguay. Photo by Ernesto Elgue.

\section{Physalaemus gracilis:}

CF-B 042 - November 13, 2011, Barra de la Laguna de Rocha, Rocha, Uruguay. Photo by Raúl Maneyro.

\section{Pseudis minuta:}

ZVCB 22547 - April, 16, 1994, Laguna de Rocha, Rocha, Uruguay. Collectors: R. Maneyro, D. Queirolo, S. Umpierrez \& R. Rodriguez.

ZVCB 22548 - April, 16, 1994, Laguna de Rocha, Rocha, Uruguay. Collectors: R. Maneyro, D. Queirolo, S. Umpierrez \& R. Rodriguez.

ZVCB 22607 - April, 16, 1994, Laguna de Rocha, Rocha, Uruguay. Collectors: R. Maneyro, D. Queirolo, S. Umpierrez \& R. Rodriguez.

CF-B 049 - March 25, 2012, Barra de la Laguna de Rocha, Rocha, Uruguay. Photo by Ernesto Elgue.

\section{Pseudopaludicola falcipes:}

CF-B 043 - August 22, 2012, Barra de la Laguna de Rocha, Rocha, Uruguay. Photo by Ernesto Elgue.

CF-B 044 - February 23, 2012, Barra de la Laguna de Rocha, 
Rocha, Uruguay. Photo by Gisela Pereira.

\section{Rhinella arenarum:}

ZVCB 4900 - February 10, 2001, Barra de la Laguna de Rocha, Rocha, Uruguay. Collector: M. Clara.

ZVCB 22670 - January 12, 1995, Laguna de Rocha, Rocha, Uruguay. Collectors: M. Santos \& R. Maneyro.

\section{Rhinella dorbignyi:}

CF-B 039 - December 19, 2012, Barra de la Laguna de Rocha, Rocha, Uruguay. Photo by Ernesto Elgue.

\section{Rhinella fernandezae:}

ZVCB 22592 - January, 1995, Laguna de Rocha, Rocha, Uruguay. Collectors: M. Santos \& R. Maneyro.

\section{Scinax granulatus:}

ZVCB 22850 - December 18, 2012, Barra de la Laguna de Rocha, Rocha, Uruguay. Collectors: E. Elgue, F. Achaval-Coppes, C. Fernandez \& G. Pereira.

\section{Scinax squalirostris:}

ZVCB 16145 - August 7, 2006, Laguna de Rocha, Rocha, Uruguay. Collectors: C. Borteiro, F. Kolenc.

ZVCB 22609 - April 16, 1994, Laguna de Rocha, Rocha, Uruguay. Collectors: R. Maneyro, D. Queirolo, S. Umpierrez \& R. Rodriguez.

CF-B 050 - March 24, 2012, Barra de la Laguna de Rocha, Rocha, Uruguay. Photo by Ernesto Elgue. 